\title{
Neuronal bursting: interactions of the persistent sodium and CAN currents
}

\author{
Justin R Dunmyre ${ }^{1 *}$, Jonathan E Rubin² \\ From Nineteenth Annual Computational Neuroscience Meeting: CNS*2010 \\ San Antonio, TX, USA. 24-30 July 2010
}

The pre-Botzinger complex $(\mathrm{pBC})$ is a heterogeneous neuronal network within the mammalian brainstem and has been experimentally found to generate robust, synchronous bursts [1]. Significant modeling research has been conducted on characterizing the dynamics of individual neurons within the pBC. $[2,3]$ It is well known that the persistent sodium current $\left(\mathrm{I}_{\mathrm{NaP}}\right)$ contributes to square-wave bursting seen in the $\mathrm{pBC}$ [4]. Recent experimental work within the pBC identified a signaling cascade that starts with presynaptic glutamate and ends with the release of intracellular calcium that activates a nonspecific cationic current $\left(\mathrm{I}_{\mathrm{CAN}}\right)$ [5]. A subsequent model demonstrated that $\mathrm{I}_{\mathrm{CAN}}$ may contribute to bursts within the $\mathrm{pBC}$ that exhibit depolarization block [6]. With these two mechanisms for generating bursts present within the $\mathrm{pBC}$, an open question is how do they combine to generate the robust bursts seen in the network? The present work seeks to analyze the result of including both $\mathrm{I}_{\mathrm{NaP}}$ and $\mathrm{I}_{\mathrm{CAN}}$ within the same model. We consider the effects of heterogeneity in the conductance $\mathrm{g}_{\mathrm{NaP}}$ of $\mathrm{I}_{\mathrm{NaP}}$ and the conductance $\mathrm{g}_{\mathrm{CAN}}$ of $\mathrm{I}_{\mathrm{CAN}}$; with this heterogeneity in mind, the model cell may be quiescent, tonically active, have only square-wave bursts, have only depolarization-block exhibiting bursts, or may show both types of bursting. Using the mathematical tools of bifurcation analysis and slowfast decomposition, we illuminate the mechanisms underlying the transitions of a model cell between the types of dynamics listed above. Our results show that, in cases where $\mathrm{g}_{\mathrm{CAN}}$ is relatively high, increasing $\mathrm{g}_{\mathrm{NaP}}$ increases the range of $g_{\text {CAN }}$ where the resultant cell has depolarization-block exhibiting bursts. On the other hand, when g $_{\text {CAN }}$ is relatively low, increasing $\mathrm{g}_{\mathrm{NaP}}$ may cause the cell to transition from quiescence, to square wave bursting, to tonic activity, to square wave bursts with high duty cycles, and finally further increase of $g_{\mathrm{NaP}}$ causes the cell to again be tonically active. The latter two transitions do not occur if $\mathrm{I}_{\mathrm{CAN}}$ is absent. The interactions of $\mathrm{I}_{\mathrm{CAN}}$ and $\mathrm{I}_{\mathrm{NaP}}$ are relevant to many systems beyond the $\mathrm{pBC}$. Individually, $\mathrm{I}_{\mathrm{CAN}}$ and $\mathrm{I}_{\mathrm{NaP}}$ have been focused on as important to rhythmic burst generation in other systems such as the entorhinal cortex [7]; however, it is likely that both currents are present in these systems. Thus, a detailed account for the interaction of $\mathrm{I}_{\mathrm{CAN}}$ and $\mathrm{I}_{\mathrm{NaP}}$ may help explain the rhythm generation encountered in other systems beyond the $\mathrm{pBC}$.

\section{Acknowledgements}

This work is supported by NSF award EMSW21-RTG 0739261.

\section{Author details}

'Mathematics, University of Pittsburgh, Pittsburgh, PA, 15260, USA.

${ }^{2}$ Mathematics and Center for the Neural Basis of Cognition, University of Pittsburgh, Pittsburgh, PA, 15260, USA.

\section{Published: 20 July 2010}

\section{References}

1. Smith JC, Ellenberger HH, Ballanyi K, Richter DW, Feldman JL: Pre-Botzinger complex: a brainstem region that may generate respiratory rhythm in mammals. Science 1991, 254:726-729.

2. Butera R, Rinzel J, Smith JC: Models of respiratory rhythm generation in the pre-Botzinger complex. I. Bursting pacemaker neurons. Journal of Neurophysiology 1999, 82:382-397.

3. Butera R, Rinzel J, Smith JC: Models of respiratory rhythm generation in the pre-Botzinger complex. II. Populations of coupled pacemaker neurons. Journal of Neurophysiology 1999, 82:398-415.

4. Del Negro CA, Johnson SM, Butera RJ, Smith JC: Models of respiratory rhythm generation in the pre-Botzinger complex. III. Experimental tests of model predictions. Journal of Neurophysiology 2001, 86:59-74.

5. Pace R, Mackay D, Feldman J, Del Negro C: Inspiratory bursts in the preBotzinger complex depend on a calcium-activated non-specific cation current linked to glutamate receptors in neonatal mice. The Journal of Physiology 2007, 582:113-125.

* Correspondence: jrd34@pitt.edu

${ }^{1}$ Mathematics, University of Pittsburgh, Pittsburgh, PA, 15260, USA 
6. Rubin JE, Hayes J, Mendenhall J, Del Negro C: Calcium-activated nonspecific cation current and synaptic depression promote networkdependent burst oscillations. Proc Natl Acad Sci U S A 2009, 106(8):2939-2944.

7. Egorov A, Hamam B, Fransen E, Hasselmo M, Alonso A: Graded persistent activity in entorhinal cortex neurons. Nature 2002, 420(6912):173-178.

doi:10.1186/1471-2202-11-S1-O4

Cite this article as: Dunmyre and Rubin: Neuronal bursting: interactions of the persistent sodium and CAN currents. BMC Neuroscience 201011 (Suppl 1):O4.

Submit your next manuscript to BioMed Central and take full advantage of:

- Convenient online submission

- Thorough peer review

- No space constraints or color figure charges

- Immediate publication on acceptance

- Inclusion in PubMed, CAS, Scopus and Google Scholar

- Research which is freely available for redistribution

Submit your manuscript at www.biomedcentral.com/submit 